\section{Arte, etiqueta e retórica: a nobreza e a santidade retratada pela cultura mineira}

\section{Art, courtesy and rhetoric: nobility and holiness portraited by Minas Gerais culture}

\section{Resumo}

A problemática abordada por este artigo é referente ao contexto do surgimento da arte mineira no século XVIII, marcada pelas origens paulistas, pela colonização portuguesa e a afirmação dos valores católicos cristãos. As obras desse período são condicionadas pela economia do ouro e por uma sociedade baseada em cânones aristocratas e escravocratas. O exame da arte proposta neste momento já nos revela os esquemas, as maneiras e os modelos da nossa época, como também suas festas e rituais indicam sua adaptação ao novo cenário urbano. A reflexão nos leva à reconstrução de um ideal político e religioso, mantido e entendido pelo clero, mas também a um imaginário sobre o poder construído pelo discurso religioso, entendido justamente pelos seus rituais, festas e cerimônias.

Palavras-chave: Arte, Modelos Artísticos, Religião, Cerimônias, Rituais, Barroco.

\section{Abstract}

The problem addressed by this article is related to the context of mining art emergence in the Eighteenth Century, marked by its Paulist origins, Portuguese colonization and the affirmation of Christian Catholic values. The works of this period are conditioned by the gold economy and by a society based on aristocratic and slave-own canons. The examination of the art proposed at this time already reveals the schemes, manners and models of our time, as well as their festivals and rituals indicate their adaptation to the new urban scene. The reflection leads us to the reconstruction of a political and
Prof. Dr. Marcos Horácio Gomes Dias

Doutor em História Social pela PUC-SP e mestre em História Social pela USP, sendo ainda pósgraduado em Arte e Cultura Barroca pelo Instituto de Filosofia, Arte e Cultura da Universidade Federal de Ouro Preto (UFOP). tualmente, é professor do Museu de Arte Sacra de São Paulo (MAS), da Universidade São Judas (USJT) e do Centro Universitário Assunção (Unifai).

E-mail:mghdias@uol.com.br 
religious ideal, maintained and understood by the clergy, but also to an imaginary about the power constructed by religious discourse, and understood precisely by its rituals, celebrations and ceremonies.

Keywords: Art, Artistic Models, Religion, Rituals, Ceremonies Baroque.

\section{Introdução}

Definir até que ponto os artistas mineiros da época estavam atrelados às regras dos tratados é sempre hipotético, mas, de qualquer forma, a bibliografia especializada consegue observar a presença desses princípios na realização e na composição da arte em Minas Gerais julgando o resultado final das obras e - ambiente artístico-cultural onde se encontravam. Há que considerar que os artistas da capitania não contavam com uma maneira única de composição, sendo difícil uma normatização metódica, mas podemos encontrar técnicas, normas, concepções e condutas que estão estritamente ligadas à tratadística e aos modelos apresentados pela época.

De uma maneira geral, a arte nas Minas Gerais do século XVIII ordenava a percepção do público e propunha um discurso específico. Procurava sempre o ponto de vista adequado e a melhor forma de compor as palavras e as imagens. Assim como a etiqueta coordenava o comportamento, os tratados de retórica, pintura e arquitetura ajudavam a coordenar as artes.

\section{A definição da arte e dos saberes no Antigo Regime e na colônia}

A ordem política, social e religiosa da monarquia do Antigo Regime se refletia no mundo colonial luso-brasileiro em uma ordem baseada nos termos retóricos e que tinha na coordenacão da igreja e dos funcionários reais o amparo para a arte. Para esse setor da sociedade, a ordem artística é encarada como algo prático, que atende a fins específicos'.

1 Sobre a percepção e os meios práticos da arte em Minas Gerais consultar Alves (1997).
Na base desse processo de significação estão bíblias e hagiografias; obras devocionais e greco-latinas; textos luso-brasileiros, espanhóis, franceses, italianos; estampas alemãs e outras produções do século XVII e XVIII. Entre essas obras, temos modelos cortesãos, tratados a partir de esquemas teológicos, políticos e retóricos, que exigem decoros específicos e a agudeza dos indivíduos. Obras como as de Góngora, Quevedo, Gracián e Tesauro compõem a inteligência do período e o processo de construção e observação das artes e das imagens, oferecendo os padrões que regem a representação hagiográfica do momento.

O exemplo maior vinha da linguagem e da literatura clássica, as quais tinham na retórica sua base de construção e refinamento ${ }^{2}$. A retórica utilizava uma série de figuras de linguagem que permitia o uso de palavras, ou grupo de palavras, que davam ênfase particular a uma ideia ou sentimento. A ênfase especial era tipicamente realizada pelo uso consciente desses termos na construção de uma oração. Aristóteles definiu a função da retórica como sendo a busca pelos meios possíveis de persuasão. Enfatizava que o argumento persuasivo teria que ser ordenado para atrair a atenção e a emoção do público. Era uma forma de influenciar o julgamento e os sentimentos das pessoas e, também, servia como uma forma de propaganda. Por isso, desde a antiguidade, essas locuções eram empregadas extensivamente pelos oradores e escritores de forma a fortalecer e embelezar seus estilos ${ }^{3}$. Em Roma, os grandes mestres da retórica foram Cícero e Quintiliano. Durante o período medieval, a retórica continuou a ser ensinada nos monastérios e nas universidades.

2 Cláudio Manuel da Costa, poeta árcade mineiro, tinha em sua biblioteca um exemplar do Il Cannocchiale Aristotélico de Tesauro.

3 O estabelecimento de instituições democráticas, na antiga Atenas, impôs a prestação do serviço público para todos os cidadãos. Aperfeiçoar uma habilidade, em oratória, surgiu, então, como uma necessidade para a vida política. Para isso, teve início uma série de estudos sobre o idioma até que se tornasse um conhecimento com propósito prático atrelado a filosofia. 
Com o Humanismo e o Renascimento do século XIV, assistimos ao fortalecimento da crenca de que a arte deveria ser ordenada e regida por tratados que versavam sobre formas de composição e representação. Isso possibilitou uma explosão da criatividade artística, a qual durou até o século XVIII. Entre as diversas e importantes obras do período, temos Petrarca, Marsilio Ficino e Pico della Mirandola. Desde o século XVI, a península itálica retoma também os estudos sobre as obras de Aristóteles. A Retórica é a obra por excelência e a agudeza domina as técnicas e as regras. Segundo Maria do Socorro:

O conhecimento da Poética de Aristóteles no século XVI, e antes, no terreno da especulação, a interpretação tomista de suas obras, repõem em cena princípios imitativos greco-latinos, normatizados em artes, retóricas e manuais de oratória latina. (CARVALHO, 2007, p. 22)

Os homens dessa época entendiam que a cultura grega tinha deixado como herança obras extremamente importantes, como a Ilíada e a Odisseia. A perfeição de seus versos indicava o início de uma tradição literária que, disseminada por todo o mundo ocidental, significava um modelo a ser seguido e reproduzido em todos os períodos da história. Esses homens buscavam também os eventos míticos e heroicos que foram temas de várias epopeias subsequentes, como aquelas que descreviam a Guerra de Tróia, para aperfeiçoar seu repertório e propor novas combinações. A Teogonia, normalmente atribuída a Hesíodo, era uma obra extremamente interessante na medida que contava a história do estabelecimento da ordem e do caos no universo, além de retratar o nascimento dos deuses Essas narrações eram modelos a serem imitados, ao mesmo tempo em que ofereciam uma série de alegorias para o mundo que se descortinava após o Concílio de Trento.

Desde então se mantém uma tradição que diferencia as cenas trágica, cômica e satírica. A tragédia é dominada por um cenário com colunas e estátuas; a comédia contenta-se com vistas comuns; e as peças satíricas são acomodadas em cavernas ou paisagens rurais. Essas obras traçam um paralelo entre os temas da literatura e da pintura e oferecem uma possibilidade visual infinita para a apresentação de um determinado discurso pelas artes plásticas. Esses recursos retóricos podiam relacionar determinadas figuras de linguagem (antíteses, hipérboles, eufemismos, ironias, metáforas e metonímias) a símbolos e alegorias do universo da pintura e da escultura.

Em todos esses casos, esperava-se que o espectador conseguisse fazer associações entre a imagem e aquilo que ela representava. Assim, era definido o que era visto de perto ou de longe, de forma clara ou hermética, de maneira simultânea, uma vez ou várias vezes. O espaço público e privado, o palácio e o templo religioso eram vistos como um cenário. A poesia era vista como uma pintura. Nesse jogo constante entre palavras e imagens, as letras clássicas reforçavam, entre todas as figuras de linguagens, as várias possibilidades do uso das metáforas e das metonímias.

Com a metáfora, os autores podiam aproveitar as semelhanças entre os termos e os correlacionar de forma a produzir um discurso mais eficaz e contundente. Nesse caso, a sabedoria estava em transportar o significado de um enunciado para outro enunciado na medida em que existam relações subentendidas entre eles. Os autores desse período costumavam dizer: "lábios de rubi", "inverno da vida", "arder em desejos".

A metonímia, por sua vez, era "[...] a substituição de sentido de um termo por outro que com ele apresenta relação lógica e constante" (FARACO; MOURA, 1996, p. 442). Essa substituição era possível na medida em que o termo escolhido apresentasse uma relação tão íntima com o seu objeto que passasse a existir como sua própria definição. Podiam dizer, por exemplo, "ele esticou as canelas" ou "comeu um prato". 
De maneira similar, no contexto plástico, o símbolo associava de forma imediata a imagem com aquilo que ela significava, representando uma relação convencional entre dois ou mais elementos. Era uma figura que substituía uma determinada coisa por uma imagem escolhida para designá-la: a espada pela função militar, a coroa pelo rei, a toga pela magistratura, a cruz pelo cristianismo etc. ${ }^{4}$

A alegoria, de maneira mais complexa, lançava mão de justaposições e associava ideias abstratas a determinadas figuras. Nesse caso, uma coisa podia ser representada por uma imagem diferente dela mesma, ou seja, daquilo que seria óbvio ou imediato. Muitas vezes, a figura alegórica transmitia por meio de uma forma humana conceitos relacionados a virtudes e vícios. Essa mediação era realizada de maneira tão eficaz que a coisa significada perdia o lugar para a imagem que agora a significava, chegando a causar a própria eliminação da primeira ${ }^{5}$. No momento em que estudamos, por exemplo, a deusa grega Palas Atena tinha deixado de ser uma representação da deusa para se tornar a própria imagem da sabedoria e o Antigo Testamento tinha se tornado na verdade uma prefiguração do Novo Testamento, deixando de ser apenas uma narrativa dos primeiros momentos da história do povo hebreu.

4 O uso de símbolos iconográficos na arte pode ser verificado já em 3000 a.C., quando as civilizações neolíticas do Oriente Médio usaram abstrações ou figuras animais para representar elementos sagrados ou da própria vida cotidiana. Assim, a deusa egípcia Hathor era associada a uma vaca e normalmente aparecia em esculturas ou afrescos como uma mulher com uma cabeça de vaca. O deus do sol Rá tinha a cabeça de um falcão e Ptah aparecia como um touro. Na Grécia antiga e em Roma, os deuses eram associados a objetos específicos. Zeus (Júpiter), o pai dos deuses, era acompanhado, frequentemente, por uma águia ou um raio; Apolo, o deus de arte, por uma lira; Artemis (Diana), a caçadora, por um arco. Além disso, os romanos aperfeicoaram o uso de símbolos alegóricos seculares. Por exemplo, uma mulher cercada por cachos de uvas e feixes de trigo seria entendida prontamente como uma representação das generosidades da terra.

5 Segundo Hansen (1986, p. 1): "A alegoria é a metáfora continuada como tropo de pensamento, e consiste na substituição do pensamento em causa por outro pensamento, que está ligado, numa relação de semelhança, a esse mesmo pensamento".
Até, ao menos, o século XVIII, pinturas alegóricas foram especialmente importantes, pois os artistas elaboraram intricados esquemas simbólicos para ilustrar questões como a vaidade, o amor, a ambição e vários sentimentos humanos. Os personagens sagrados eram alegorizados com figuras, roupas e atributos característicos para a sua rápida identificação. Era comum a representação de objetos neutros com um profundo significado religioso, como elementos de pesca e a pomba, que simbolizavam Cristo e o Espírito Santo, respectivamente. Muitos santos foram associados a objetos relativos à sua história: São Pedro às chaves ou Santa Catarina a uma roda quebrada ${ }^{6}$. Nas igrejas de Minas Gerais, essas referências podiam ser encontradas nos altares, nos arcos e no vestuário. Podemos encontrar a balança como símbolo da justiça de São Miguel, o Monte Carmelo como símbolo dos carmelitas e o lírio como símbolo de São José. Objetos como joias, moedas e instrumentos musicais personificavam os prazeres vãos da vida, enquanto crânios, ampulhetas e velas queimadas e apagadas eram lembranças da morte ${ }^{7}$.

A inspiração vinha também da astrologia, da cabala e dos hieróglifos ${ }^{8}$. Na Europa, vários

6 Os Atos dos Apóstolos eram utilizados, por exemplo, para mostrar e ressaltar a vida dos primeiros santos.

7 No mundo contemporâneo, a arte se transformou em algo altamente individualista e o uso de símbolos e alegorias quase desapareceu. Temos algumas exceções como o Cubismo, o Dadaísmo e o Surrealismo. $\mathrm{Na}$ arte popular, imagens como objetos, jornais, sopas enlatadas e fotografias tornaram-se símbolos de genuínas iconografias que refletem a cultura moderna.

8 Os hieróglifos egípcios são muito estudados nesse período. Em um único formato, um pequeno conjunto de pequenas imagens consegue propor um significado e uma ideia instantânea. Toda a cultura neoplatônica do renascimento usa do hieróglifo como modelo para a construção de emblemas e empresas. A própria talha das igrejas barrocas apresenta uma estrutura plástica que pode ser confundida com uma estrutura hieroglífica. A talha é um emblema posto em pé. Vemos assim uma grande circulação de tratados de decifração de alegorias egípcias, empresas, emblemas e imagens: Hieroglyphica de Valeriano em 1575, Hieroglyphica de Horapolo de 1551, Emblemata de Alciato de 1522, Iconologia de Ripa de 1593, Hypnerotomachia Poliphili de Francesco Colonna de 1499 etc. 
artistas plásticos como Botticelli, Michelangelo e Arcimboldo pesquisaram de forma profunda o uso da alegoria e buscavam suas fontes. Patrocinados pelos mecenas da época, vários humanistas reliam os antigos e procuram novas formas de composição artística. Obras como a Ilíada, a Odisseia, as Metamorfoses e a Eneida eram revistas nas concepções de interpretação dos homens do momento.

Diante dessa vasta rede simbólica, existem possibilidades infinitas de relações entre os diversos termos. No processo de identificação e codificação das imagens temos ainda os emblemas e as empresas.

Os emblemas podem ser usados em igrejas, edificações públicas, aparatos festivos, frisos, arcos, vasos, vestuários, armaria, livros etc. Compõe-se de símbolos imagéticos que correspondem a um significado fechado e hermético que representa ou diz respeito a uma corporação, instituição etc. Segundo Hansen, pode ser colocada a imagem de um diamante, simbolizando um homem forte; a cegonha como a vigilância; a lança como a liberdade; o leão para a força etc. Vem, muitas vezes, acompanhado por um epigrama, em latim ou língua vernácula, que ajuda a compor o "texto" a ser lido e coloca em palavras lemas ou palavras de ordem. As imagens garantem uma correspondência com aquilo que está sendo representado e tem uma preocupação moral.

As empresas são referências simbólicas de cunho particular e individual. Pelo seu caráter específico, apresentam imagens e epigramas de difícil entendimento, já que diz respeito apenas a quem as porta. Geralmente remete-se a um propósito individual e é apresentada de forma obscura e engenhosa. As empresas são usadas, principalmente, em escudos e bandeiras?

Nos retábulos mineiros, podemos encontrar as cartelas como exemplo das questões levantadas acima. Elas representam o santo, ou a associação que o cultua, por meio de uma determinada simbologia que é emoldurada por

9 Consultar PRAZ, 1989. uma espécie de brasão. Essa cartela localiza- se sobre cada altar, de forma a deixar claro o espaço de cada entidade dentro do templo. Os símbolos, ou alegorias, expostos nessas cartelas são herdeiros da heráldica europeia.

É importante perceber na composição desses retábulos e altares que o artista, erudito ou não, busca aquilo que é norma ou aquilo que é de uso "correto". Mesmo o artista que não tivesse uma cultura formal, como é o caso de Minas Gerais, estava embebido dessa atmosfera, pelas próprias circunstâncias do seu tempo. Por rezar para santos que já seguiam as normas artísticas do seu tempo, por olhar gravuras em Bíblias importadas e por conviver com artistas vindos da metrópole, esses homens aproveitavam os modelos e seguiam procedimentos e princípios imitativos ditados pela época. Os próprios artistas portugueses que estavam em Minas Gerais traziam em sua memória as formas artísticas cultuadas nas suas regiões de origem. Nesse momento, proliferavam em Portugal tratados, cartas, discursos e textos moralizadores, que foram difundidos por preceptores espanhóis e italianos e que ajudaram a compor a mentalidade culta do país.

No mundo religioso português, os usos dados a essas imagens refletem os ditames moralizantes da Contrarreforma. Segundo Hansen, o decreto sobre as imagens durante o Concílio de Trento prescrevia:

\footnotetext{
Devem ser evitadas imagens que possam ser causa de erro para pessoas rudes; as escrituras devem ser seguidas de perto; deve-se evitar a superstição; mais que tudo, a luxúria. Conselho geral aos bispos: evitar coisas profanas/imodestas nas igrejas; censurar previamente imagens insólitas. (HANSEN, 1999, p. 03)
}

A Igreja sempre se preocupou com os usos das imagens nos ambientes sagrados. Para o papa Gregório Magno: "A pintura é a história do ignorante" (apud BOHRER, 2004, p. 3). Segundo Jens Baumgarten: 
A questão das imagens foi um dos pontos principais das disputas interreligiosas. 0 Concílio de Trento (1545-1563) tornou-se uma guinada histórica essencial no que diz respeito à questão do conflito teológico sobre a importância das imagens, sobretudo do lado católico. Os teólogos pós-tridentinos desenvolveram uma concepção estética relevante do ponto de vista da história da mídia, mas também utilitária e politizante. Os bispos e teólogos católico-reformadores como Carlo Borromeo (1538-1584), Gabriele Paleotti (1522-1597), Roberto Bellarmino (1542-1621) e Antonio Possevino (1533-1671) escreveram em fins do século XVI os principais tratados teóricos-teológicos sobre a arte sacra e a concepção teórica do sermão no período pós-tridentino. (BAUMGARTEN, 2004, p. 306)

Para que não se ofendam os direitos da história, há que se tenha presente que é lícito ao pintor e ao escultor embelezar e ilustrar o melhor possivel as narrativas, mas em nenhum caso está permitido contradizer a verdade das mesmas e desfigurar ou não reconhecer a inveterada tradição de qualquer fato. O II Concílio de Nicéia, que ocorreu em 787 d.C., já tinha ocasionado um intenso debate sobre o uso de imagens pelas igrejas cristãs. Foi o sétimo concílio ecumênico e foi convocado por Irene, imperatriz do Império Romano do Oriente, e presidido por 350 bispos, a maioria dos quais eram bizantinos. Os Imperadores Leão III (717-741), Constantino V Coprônimo (741-775) e Leão IV (775-780) favoreceram a iconoclastia. O grande defensor da utilizacão das imagens foi João Damasceno (m. 749). Durante as assembleias, foi lida uma carta do papa em franco favor às imagens. Apesar das fortes objeções dos iconoclastas, o consetho validou a reverência a elas e ordenou sua restauração nas igrejas por todo o Império. Esse concílio aprovou o reconhecimento e a veneração, e não a adoração, dos ícones religiosos. Nos tempos modernos, precisamente acerca disso, o decreto do sagrado Concílio de Trento ordenou que se evitassem nas pinturas sagradas a falsidade e todos os erros a fim de que as imagens devotas não apresentassem nada capaz de escandalizar as almas singelas. Diz, expressamente, esse decreto: "de modo que não apareça nada desordenado, recortado com mesclas ou inversões, nada profano e nada indecente" (ARENAS; HUGAS, 1983, p. 146).

Segundo Cardeal Federico Borromeo:

Um requisito necessário da beleza é o de evitar-se qualquer nu que não seja estritamente exigido pela verdade dos mistérios, ou que possa ofender a delicadeza de ânimo ou diminuir a devoção dos observadores. (...) Deste modo vemos a inconveniência daqueles que pintam o divino Menino mamando de forma que mostram nus os seios e o colo da Santa Virgem, quando estas partes não se devem pintar a não ser com grande cautela e modéstia. Não poucos retratam nuas as pernas de santos e santas e as aproximam umas das outras de um modo que podem despertar no ânimo algum pensamento pernicioso. (BORROMEO apud ARENAS; HUGAS, 1983, p. 146-151)

O Cardeal deixa claro que:

\begin{abstract}
As cores são quase como palavras que, percebidas com a vista, penetram não menos que as vozes percebidas pelo ouvido, e o primeiro esboço da coisa que se tem que pintar é quase igual à elaboração de razões e argumentos. Por isso acontece que até o vulgo e a multidão ignorante compreendem a linguagem da pintura e com não menor eficácia que entre os homens prudentes. (BORROMEO apud ARENAS; HUGAS, 1983, p. 146-151)
\end{abstract}

Na composição desses temas, Cesare Ripa é o autor que inspira os artistas da época, pois já trabalhava com o modo de fazer aristotélico, baseando-se na retórica, no exemplo dos hieróglifos egípcios e nas imagens de tradição greco-latina. Tomando o discurso como modelo, retoma textos de Horácio na composição de suas imagens. Se uma definição escrita é feita por uma economia de palavras, assim seria a imagem alegórica que representaria, de forma 
sintética, um pensamento. Ripa propunha alegorias adequadas e composições artísticas que seriam fiéis a determinadas interpretações que seriam utilizadas também pela Igreja de Roma.

A Iconologia de Cesare Ripa, que tem sua primeira edição em 1593, traz diversas alegorias e modos como devem ser representadas. A partir de 1603, é editada em Augsburgo com gravuras ${ }^{10}$. Foi muito utilizada por diversos artistas ditando as regras de representação por todo o Antigo Regime (HANSEN, 1986, p. 87-92).

Em relação às formas de fixação da cultura cristã, temos a sobrevivência de coleções medievais, como a "Legenda Áurea", que fazia uma compilação da vida dos santos e foi escrita pelo arcebispo de Gênova Jacobus Voragine. Essa obra tornou-se muito popular no período e serviu de modelo para pintores e escultores, até o final do século XVIII. Temos que lembrar ainda os Exercícios Espirituais de Inácio de Loyola e de doutores da igreja que dominam a prosa cristã e os modelos a serem seguidos: São Jerônimo, Santo Agostinho e São Tomás de Aquino. A principal realização de São Jerônimo foi a tradução da Bíblia. Conhecida como Vulgata, foi desde então a versão latina modelo e sua influência no mundo ocidental foi enorme. Santo Agostinho foi um dos mais influentes de todos os pensadores europeus. Entre suas principais obras, A Cidade de Deus e Confissões, podemos notar o uso do estilo clássico da retórica de Cícero de uma maneira individual e comovente que expressa um grande senso de convicção cristã. São Tomás de Aquino é um dos principais modelos pela sua releitura de Aristóteles e seu De Regimine Principum (CURTO, 1998, p. 147).

Além desses nomes, temos ainda Giovanni Andrea Gilio, o qual trata sobre a pintura sacra, Gian Domenico Otonelli e Pietro Berretini da Cortona, que falam sobre a pintura e a escultura,

10 "A personificação de todas as ideias abstratas relacionadas com a vida humana - em uma palavra, das alegorias -, foi a grande tarefa de Cesare Ripa (cerca de 1560-1623). A sua Iconologia, editada em Roma, em 1593, ilustradas muitas das edições seguintes, a partir de 1603, tornou-se famosíssima, foi livro indispensável em todos os ateliers e academias até quase fins do século XVIII". (MAIA, 1990, p. 26) e Charles Le Brun, o qual trata sobre a imaginação do espectador em contato com a obra. Esses autores determinaram também regras para a arquitetura e para ornamentação das igrejas. A planta retangular era excelente, pois conseguia estar ladeada de retábulos e altares com imagens de santos. Pela sequência das pinturas e das esculturas, a nave da igreja poderia ser "lida" como um livro. Devido ao drama que exibem, as igrejas tornam-se um espetáculo apresentado num teatro sagrado" ${ }^{17}$.

Dessa maneira, as imagens suscitadas por essas obras podiam condenar ou defender algo, aconselhar ou desaprovar alguma ação, louvar coisas honradas e rejeitar os vícios. As definições que essas obras possibilitavam permitiam a construção de um discurso sobre a sociedade que se vivia e a imagem que os próprios indivíduos tinham de si e do mundo. Os antigos eram, assim, fontes de interpretação e de novas possibilidades combinatórias, pois eram ricos em sentidos e significações ${ }^{12}$. A alegoria greco- latina era submetida aos cálculos astronômicos e combinada às interpretações religiosas cristãs $^{13}$. O simbolismo disfarçado das cenas era uma forma de mostrar o sentido elevado da arte no estudo da realidade e da natureza, revelando seu sentido religioso. Muitas vezes um acontecimento histórico e real poderia ser visto como uma alegoria dos atos de Deus sobre os homens. Deus não fala apenas por palavras, mas também por atos e imagens. Nesse jogo, a Bíblia teria o sentido literal e o sentido espiritual. Pela tradição religiosa, a antiguidade é antecipadora dos mistérios das escrituras e das interpretações dos pais da Igreja:

11 Conhecido como Theatrum Sacrum.

12 Segundo HANSEN (1986, p. 48): "Na prática de interpretação alegórica dos primeiros Padres da Igreja confluem, assim, vários dispositivos, como a Retórica greco-latina, a etimologia, a filosofia platônica e neoplatônica, a exegese judaica da Torah, a astrologia persa etc."

13 "A arte é a tradução visível dessas potências astrais visíveis, como enigma: sua formulação mais apropriada é o hieróglifo, cuja forma alegoriza, de modo simultâneo, a simplicidade e a unidade divinas. Retoricamente, assim, a obra de arte aproxima-se da tradição de tota allegoria, alegoria fechada ou perfeita. Para compô-la, o artista opera a magia através da força das imagens e figuras. A magia é um conjunto de cálculos numéricos ou de operações químico-físicas que a astrologia e a analogia dotam de poderes 'mágicos"' (HANSEN, 1986, p. 73). 
A principal dessas especificidades é o modo qualitativo pelo qual concebem a temporalidade como emanação ou criação de Deus que inclui a natureza e a história, subordinando-as providencialmente no projeto da salvação. A representação propõe que a natureza e a história são simultaneamente efeitos criados por essa Causa e signos reflexos dessa Coisa [...] A concepção relaciona a experiência do passado e a expectativa do futuro como previsibilidade, pois afirma-se que a Identidade de Deus, causa primeira, repete-se em todas as diferenças históricas do tempo, tornando análogos ou semelhantes todos os seus momentos, desde a criação até o presente dos intérpretes. (HANSEN, s.d., p. 46)

Em Minas Gerais, os artistas realizavam suas obras de acordo com a encomenda recebida. Pelos acordos firmados entre entalhadores, pintores e encomendantes, já se estabelecia o tamanho das imagens, a iconografia específica e a adequação necessária para o espaço que ela ocuparia ${ }^{14}$. Afinados que estavam com a cultura artística advinda da Contrarreforma, percebemos que as imagens mineiras são sérias e graves, estão prontas para ensinar e comover. Assim como os diversos textos e tratados abusavam dos adjetivos na composição dos personagens, as imagens faziam o mesmo por meio dos seus atributos, símbolos e posições dos corpos (HANSEN, 1999, p. 1).

Para o pesquisador, essas obras parecem querer resumir em uma única imagem toda a informação possível e necessária para reconhecer o discurso da época: brasões, escudos, armas militares, lanças, trombetas, capas, coroas, cetros etc. Nessa mentalidade alegórica, podem ser personificações de figuras nobres,

14 Coelho (2005, p. 233) coloca: "O escultor ou entalhador idealizava e entalhava a escultura segundo a encomenda recebida, que, em geral, já determinava se seria totalmente esculpida ou de vestir. Escolhia a madeira de acordo com o tamanho da imagem, decidia se seria oca ou maciça, feita em um só bloco de madeira ou em vários blocos e peças". tradicionais, mitológicas e simbólicas, que são resgatadas conforme o costume da representação religiosa do momento.

Para localizar os fatos dessas narrativas históricas e sagradas, o artista mineiro compõe ainda fundos de cena que retratam paisagens distantes e rostos exóticos. Para a geografia do Antigo Testamento e da Terra Santa, pinta desertos, seres fantasiosos e palmeiras. Temos personagens com costumes árabes - túnicas amarradas na cintura, capas e turbantes -, os quais são representantes do imaginário europeu e da construção que os ocidentais faziam do oriente próximo ${ }^{15}$.

Para os personagens do Novo Testamento, temos um cenário codificado pelo drama e pela tragédia. Essas obras buscavam o passado greco-romano ao retratar vestígios arquitetônicos e colunas que mostravam a antiguidade. As figuras bíblicas que conviveram com Jesus Cristo e os santos posteriores portam esferas e globos, que são uma invocação do poder absoluto (CHEVALIER; GHEERBRANT, 2009, p. 472).

Vemos, assim, que a maior parte da tradição utilizada pelos artistas do período se baseava nessas estruturas que eram usadas de forma teológica e como uma maneira de atacar as várias possibilidades da religiosidade popular, que surgiram durante o período colonial.

\section{A definição dos gestos e das atitudes no Antigo Regime e na colônia}

Além das representações artísticas, os homens precisavam estar atentos aos bons comportamentos para uma relevante educação religiosa. A leitura religiosa de mundo do

15 Para Montesquieu, por exemplo, o poder despótico seria uma espécie de monarquia no qual todas as ordens da sociedade seriam abolidas, os indivíduos ficariam sob o julgo de um só governante, que teria, em suas mãos, todos os poderes, governando por meio do terror. Montesquieu, em Do espírito das leis identifica o governo despótico, algumas vezes, com os governos que existiam no oriente. 
universo luso-brasileiro se coadunava muito bem com uma produção de significados baseada em valores cortesãos. Nessas práticas, - modelo da hierarquia e da superioridade divina se estabelecia a partir de uma submissão política e simbólica ao rei e às regras sociais. O Rei, que também era um representante de Deus na terra, exigia indivíduos que se definissem pela piedade, pela razão e pela discrição. O bom homem era aquele que conhecia o seu lugar e que sabia discernir os protocolos, o uso dos diversos discursos e as melhores ações para determinadas situações e ocasiões. Assim, temos critérios de produção de modelos e um ideal para a educação dos indivíduos. Numa sociedade católica e piedosa, os tratados ensinavam caminhos para a representação, para o bom comportamento e para a atividade intelectual ${ }^{16 .}$

Um habitante de Minas Gerais encontraria o conteúdo para esse tipo de civilização dos costumes nos hábitos que vinham da metrópole. Na Europa, os modelos de uma boa formação intelectual, cultural e artística passavam pelas leituras de Giovanni Della Casa ${ }^{17}$ Baltasar Gracián, Diego Saavedra Fajardo, António de Guevara, Torquato Acetto e Bal-

16 Podemos ver que: "Desde o século XIII a Europa preocupa-se em refinar os gestos. Regras de comportamento já se caracterizavam pelo próprio ritual de juramento da vassalagem feudal. Tratadistas como Erasmo, Giovanni Della Casa e Courtin, já na Idade Moderna, preocupam-se com gestos como assoar o nariz, cuspir ou se portar na mesa. O costume de servir os alimentos com as mãos, aos poucos, exige o uso do talher e o uso do lenço implica em limpar e esconder certas substâncias que provêm do corpo. Atos que até então eram considerados naturais e como uma extensão das necessidades humanas são considerados suspeitos e de pouca dignidade. O corpo humano é visto como "templo do Senhor" pela doutrina eclesial e julgado a partir da ideia de higiene. As normas de comportamento e etiqueta apropriam-se dessa mentalidade e reúnem uma série de regras de atitudes para viabilizar o melhor uso do corpo dentro dos parâmetros aceitos pela religião e pela organização social. A ideia de "saúde" ratifica o controle e justifica ações de origens sociais. Dessa maneira, se opera o controle da violência individual e particular, tornando mais fácil o domínio político e o viver em sociedade". (DIAS, 2000, p. 93-4)

17 Autor adotado pela Companhia de Jesus em seus colégios. dassare Castiglione. Todos eles tratavam dos indivíduos por meio da discrição, do engenho e da agudeza, revelando principalmente uma sociedade baseada em códigos de honra ${ }^{18 .}$ Montesquieu, que era um bom representante dessa sociedade aristocrática, apesar de ser iluminista, afirmava que a honra não era apenas um estilo de vida, mas também toda a razão do poder que uma classe poderia auferir.

Nesses termos, a melhor forma de demostrar a honra é mostrar sua perspicácia e agudeza, que é uma maneira específica de perceber os modelos culturais e entender seus significados. Por ela, o indivíduo molda seu comportamento a partir das convenções e tira proveito delas. Não é um produto apenas individual, mas se define como um código específico de comportamento generalizado, que define a fé, os afetos, os hábitos, as relações, as falas, as escritas e as representações artísticas. Esses gestos e atitudes são coletivamente partilhados. Por isso, temos os tratados artísticos e literários, os livros de etiqueta e de aconselhamentos aos príncipes e as obras pedagógicas do momento. Esses modelos teatralizam as relações sociais e políticas, oferecendo possibilidades de representações adequadas a uma grande variedade de situações possíveis.

Pensando na divisão social fortemente marcada pela existência das irmandades e ordens terceiras em Minas Gerais, vemos que o pertencimento a um determinado grupo:

[...] comportava certos direitos, mas também certos deveres. E, sobretudo, uma obrigação de assumir em tudo uma atitude social correspondente ao estado, atitude que a teoria moral da época definia como "honra" (honor). Por oposição à virtude (virtus) - disposição puramente interior -, tratava-se de uma disposição externa, de se comportar de forma conveniente as regras sociais do seu estado. (HESPANHA; XAVIER, 1993, p. 131)

18 Temos aqui ensaios para uma virtude cristã, o renascimento do aristotelismo, o reforço do anti-maquiavelismo e uma busca por leituras de Tácito e Sêneca. 
O que temos aqui são conceitos trabalhados pelos humanistas florentinos Landino, Ficino e Pico della Mirandola ${ }^{19}$. A busca é por uma educação baseada nos preceitos da antiguidade, mais precisamente na cultura greco-romana, que trazia consigo a retórica e a filosofia. Aqui estariam os modelos a serem estudados e imitados. Desse ideal sairia uma série de manuais e textos de aconselhamentos políticos e morais que versavam sobre letras, armas e assuntos piedosos.

Segundo Ladurie, em uma sociedade de valores de corte, as ações entre os indivíduos acabam por acontecer de forma teatral, na qual cada um é ator e espectador e todos estão presos a uma mesma situação. O sujeito é aquilo que demonstra e representa na coletividade. Nesse caso, o luxo e os gastos excessivos são essenciais e demonstram a sua posição na hierarquia social e política. A aparência é o espaço do poder. Para isso, podemos pensar não só na vida da corte, como na vida eclesial e em tudo que demanda em construções de igrejas, aparatos visuais para os rituais, objetos para os sacrifícios e cerimônias diversas. As próprias indumentárias eclesiais seriam um bom exemplo de distinção pela aparência. Segundo José Pedro Paiva:

\footnotetext{
O que determinava a procedência num cerimonial e que acabava por configurar as modalidades de etiqueta nele seguidas era a dignidade. Ora este conceito de dignidade, que podia depender de uma vaga representação que um grupo de pessoas atribuía aos seus múltiplos componentes, do exercício de um poder ou jurisdição, da hereditariedade, das funções que se desempenhavam ou de um privilégio que a própria lei estipulava, não se circunscrevia à esfera da ação política. Era um conceito estruturante da própria ordem social e que, por conseguinte, se inscrevia por toda a sociedade. (PAIVA, 2001, p. 92)
}

O sentido dessa sociedade estava em manter a sua rigidez, manter a hierarquia social geracão após geração e permitir pouca mobilidade

19 Estes autores revisitam o conceito ciceroniano de virtu. fora da posição para o qual uma pessoa tivesse nascido. O sentido religioso, que muitas vezes acaba adquirindo, ajuda nessa manutenção e na falta de contestação ao sistema. Assim, com um sentido quase divino, o sistema do absolutismo monárquico torna-se seguro pela reivindicação e pela relação com o sagrado que demonstra ${ }^{20}$.

Fora da corte e da sede do governo, a monarquia conta com a igreja e com as ordens religiosas criadas pelo movimento contrarreformista. Dessa maneira, consegue manter uma rede de pequenos poderes derivados dessa instância maior, que é o alicerce do reino e dos seus impérios. Nos campos e nas colônias latino-americanas, foi lançada uma subdivisão de posições religiosas, sociais e políticas, como num eixo vertical, que liga a família real e o papado aos mais distantes fidalgos e religiosos que assumem essas respectivas funções. Na ponta extrema desse eixo, nas colônias, cria-se uma clientela particular que gira em torno desses funcionários reais e dessa hierarquia religiosa que se torna a elite dessas regiões. Segundo Júnia Ferreira Furtado:

A sociedade setecentista procurava-se
organizar de forma hierárquica e ex-
cludente. Porém, no Reino e na distante
América portuguesa, a realidade estava
muito longe dos modelos rígidos que de-
veriam ser seguidos. $O$ viver em colônias
não deveria constituir-se em experiência

20 "Em Portugal, Diogo Ramada Curto já sublinhou como, durante o reinado de D. Manuel I, houve um grande trabalho empreendido por cerimonialistas na tentativa de construção de uma 'verdadeira simbólica do Estado', projeto que utilizou múltiplas linguagens, sustentando ainda como, durante a Restauração, houve uma intensificação do trabalho de organização das cerimônias de corte. [...] A importância crescente atribuída às cerimônias públicas pode ainda deleitar-se pelo crescente movimento de publicação de 'regimentos', 'cerimoniais', 'relações' ou 'memórias' de festas e outras celebrações, particularmente dinâmico na esfera de cerimônias ligadas à vida eclesiástica e religiosa e pela proliferação dos cargos de mestre-de-cerimônias, que se podiam encontrar nas dioceses auxiliando os prelados, nos cabidos das sés catedrais, nas colegiadas, nas misericórdias, na Inquisição ou nas congregações religiosas". (PAIVA, 2001, p. 76-77) 
totalmente nova e radicalmente estranha. Herdeiros dos laços e dos costumes metropolitanos, era necessário que os colonos partilhassem dos mesmos valores, mesmo em meio à exótica natureza, exuberante e rica, mas também impenetrável e assustadora, como acentuaram os primeiros cronistas da época. A diversidade de raças, com hábitos e costumes diferentes dos da metrópole, e a escravidão, criavam novo cenário além- mar. A sociedade colonial fluida, que se movimentava com maior facilidade, misturava brancos, índios e negros, incorporava novas culturas, e criava uma sociedade que, se, por um lado, tinha Portugal como referência, por outro, era diferente. (FURTADO, 2001, p. 397)

Em Minas Gerais, a ordem é dada segundo a constituição de suas cidades e na movimentação de sua sociabilidade, incrementando uma vida urbana, de caráter ímpar dentro da colonização portuguesa na América. A sociabilidade tem outro atrativo daquele dos grandes latifúndios de então. As relações entre os indivíduos são mais intensas e as normas de convívio tornam-se uma preocupação mais constante. Ao mesmo tempo em que trazia consigo a marca e a definição dos papéis sociais, entre brancos e negros, fidalgos e desclassificados, apontava para uma nova forma de sociabilidade causada pela mineração, pelas diversas possibilidades dos indivíduos de se autossustentarem, pela inserção no comércio e pela alforria conquistada ou comprada. Em Minas Gerais, a ordem estabelecida sofria com a vontade de ascensão dos emergentes da economia mineradora ${ }^{21}$.

21 A todo momento, podemos verificar comportamentos e atitudes de dissolução das barreiras artificiais entre as diversas camadas sociais. A severidade do sistema foi grandemente quebrada pelo luxo das negras libertas, pela atuação dos artistas mulatos, pelas relações de concubinato, pelo comportamento pouco exemplar do clero local e pela mobilidade dos indivíduos pelos sertões, vales e montanhas. Podemos encontrar algumas vezes homens de baixas extrações subindo degraus sociais e tendo posições impensáveis no poder burocrático da capitania.
Eram nessas vilas e arraiais que estavam as principais igrejas e instituições públicas, onde aconteciam as principais festas e onde moravam as pessoas letradas. Essa elite urbana era formada por funcionários da coroa, comerciantes, militares, donos de minas e escravos, fazendeiros. Essas cidades tornavam-se centros irradiadores de costumes e modas no meio de um vasto território despovoado, de gente inculta e que não fazia para manter a sua subsistência.

O espaço urbano era, por excelência, o lugar onde as diferenças sociais ficavam bem marcadas. A necessidade do convívio fazia com que a população local realizasse reuniões noturnas, banquetes, bailes e leituras em voz alta. Ocorriam cerimônias solenes que se organizavam em torno das mais distintas autoridades: bispos, dirigentes e governadores. Ofereciam-se festas em ocasiões relativas à família real e aos governantes: nascimento, casamento e morte. As damas mais ricas apareciam vestidas com a última moda francesa e trechos de óperas podiam ser ouvidos.

Por sua vez, o teatro era um grande acontecimento social. A presença nele era a presença na própria sociedade ali representada. Seus compartimentos, frisas e balcões deixavam clara a divisão e a estruturação social. Ao contrário do teatro grego que unia as pessoas, o teatro no Antigo Regime separava e marcava os respectivos lugares dos indivíduos ${ }^{22}$.

Além disso, temos, na vida das irmandades religiosas mineiras, e no culto aos santos, 0 sentimento gregário e a sensação de pertencimento a uma coletividade. Por meio das festas religiosas, o sagrado fazia-se presente e toda uma sorte de eventos poderia ocorrer, marcando a sociabilidade da capitania e trazendo sentido para a vida da mineração.

22 No caso de Minas Gerais, podemos constatar que, nas diversas encenações teatrais, e nas diversas comemorações, temos uma participação ativa dos árcades mineiros. Cláudio Manoel da Costa foi o mais importante nome que se dedicou a esse tipo de texto e narração. 
O calendário das festas era dado pelas datas relativas à vida do rei e aos momentos litúrgicos. Desde o início da colonização do Brasil, essas datas eram relacionadas ao tempo das safras, da moagem da cana, à mineração ou à vida nas cidades. No geral, comenta Mary Del Priore (1994, p. 13): "Essas festas são distribuídas em dois grupos distintos: as festas do Senhor (Paixão de Cristo e demais episódios de sua vida) e os dias comemorativos dos santos (apóstolos, pontífices, virgens, mártires, Virgem Maria e padroeiros)".

Passando um olhar mais amplo pelas manifestações ocorridas nas Minas Gerais do período, vemos que essas ocasiões exigiam um gasto razoável da parte daqueles que participavam delas. Exigia-se toda uma série de vestuários e aparatos para que acontecessem. Podemos identificar um lugar de destaque para tecidos finos e luxuosos, pedrarias, joias, fios de ouro, capas, chapéus, botas e toda a sorte de adereços. Ao retratar esses santos e santas, não economizavam no seu aparato visual. As cerimônias eram entremeadas por falas, rezas e discursos laudatórios, celebradas dentro ou fora das igrejas.

Nesses momentos, não só as figuras santas eram exaltadas, como o próprio rei era lembrado em sua realeza pelos próprios adereços usados pelas invocações. Essas imagens eram retratadas com mantos, cetros e coroas, além de aparecerem dignificadas em andores, pálios, tronos e altares ricamente ornamentados. Algumas manifestações dos rituais religiosos podiam ser correlatas aos seus congêneres reais (beija-mão). Podemos identificar um espraiamento dos gestos e do discurso real em todas essas ocasiões. Segundo Laura de Mello e Souza:

No mundo do Antigo Regime, a sociedade e a religião não constituíam instâncias separadas. Uma festa de cunho religioso podia ao mesmo tempo exaltar o Santíssimo Sacramento, o novo bispado e, por meio deles, o monarca cristão que a tudo presidia assim como os seus vassalos obedientes e piedosos, de quem se esperava tanto o zelo da coisa pública quanto à observância da fé (Mello E Souza, 2001, p. 187).

As várias monarquias se encontravam em Minas Gerais: os congados, as cavalhadas, os reisados etc. Festas como a coroação de Nossa Senhora mostravam como o amor nobre e cortês poderia ser divinizado e colocado numa relação direta com Deus. Nessas cerimônias, ocorria uma transposição de condutas cavalheirescas às figuras sagradas. Mesmo no universo da cultura negra e escrava podemos encontrar tais manifestações. Eram reconhecidos os reis do Congo, os Reis Magos, Carlos Magno e os doze pares de França, além do rei de Portugal. A eleição de reis e rainhas negros foi uma das formas de escravos e ex-escravos cultuarem Nossa Senhora do Rosário na Minas colonial. Em alguns dos cortejos desses reis negros temos a descrição de toda a hierarquia da "nobreza" da festa: rainha, príncipe-regente, princesa regente, procurador geral da coroa, marquês, duques, condessas, guarda real, aias e alabarda. Esses indivíduos vestidos de nobres se encontravam nas festas e se prestavam homenagens. Segundo Marina de Mello e Souza:

\footnotetext{
Os mantos, roupas especiais, coroas, cetros e tronos são descritos por diversos observadores das congadas e aparecem em imagens que registraram essas ocasiões. As roupas provavelmente eram feitas por iniciativa das pessoas que as vestiam, sendo mais um indício do esforço financeiro exigido para a ocasião. Misturando trajes europeus, como vestidos longos, casacas, calções e mantos, com turbantes e tangas, da mesma forma que joias e sabres eram usados junto com penas de avestruz e máscaras, a corte festiva se apresentava como síntese de elementos díspares, lida como farsesca pelos observadores que as registraram. (MELLO E SOUZA, 2002, p. 217)
} 
A historiografia especializada nesse tema nos lembra, a todo momento, que os títulos não só eram usados pela nobreza europeia como também pelas classes dominantes africanas após seu batismo e conversão ao cristianismo. Dessa maneira, o uso de tais codificações no Brasil não significava apenas uma lembrança da Europa, mas também uma referência aos reinos da África Centro-Ocidental.

Essas festas sugerem que as monarquias sempre tiveram na história dos homens uma relação com o sagrado. Nesse sentido, o rei seria a cabeça de um corpo místico, no qual todos os indivíduos se encontravam e cumpriam cada um o seu papel. Após sua morte, a sociedade continuaria intacta e segura já que sua descendência garantiria a existência da monarquia. Dessa maneira, o rei é o símbolo maior de toda a sociedade, mas a sacralidade estaria na realidade no corpo social como um todo. "O que é divino é a monarquia e não o rei" (SOUZA, 2002, p. 26).

Percebemos, assim, que essas monarquias absolutas tinham uma relação estreita com os mitos que a fundamentavam. Jose Manuel Nieto Soria, quando estuda as monarquias ibéricas, percebe o quanto os poderes dos reis portugueses se fundamentavam em lendas, histórias míticas e crenças, desde suas origens. Na construção da imagem dos monarcas e na própria história de Portugal, encontraremos uma série de passagens ligadas a sonhos, profecias, aparições e milagres. O próprio sebastianismo seria uma dessas histórias. Vários autores retomam a construção do mito de D. Sebastião e lembram a vitória na Batalha de Ourique, em 1139. A despeito do exército pouco numeroso, e com a ajuda de Deus, aconteceu aquilo que parecia um milagre: a vitória dos portugueses. Segundo esses pesquisadores, a aparição de Jesus Cristo a D. Afonso Henriques teria sido o sinal da ajuda divina e a prova da intervenção dos céus na história de Portugal. Aquilo que funda e conta a origem da nação nos remete a uma história mítica e sagrada. Essas crenças realizavam de fato uma ligação entre o poder real e o poder religioso, tornando-se algo fundamental na transmissão do sentimento de ordem social e política.
Os mitos traziam essa força fundadora, a certeza da solidez desses governantes e escondiam os conflitos sociais e políticos, quando não os respondiam por si mesmos. Os mitos sempre tiveram um papel de destaque no entendimento e na explicação do mundo das sociedades pré-industriais. Segundo Hilário Franco Júnior, "o mito sempre foi a forma privilegiada de uma sociedade arcaica enunciar e aprender essa essencialidade do universo" (FRANCO JR., 1996, p. 38). Os mitos falam da vida interior, servem de modelo e podem dar um centro à vida dos indivíduos. Tornam-se referências para questões diárias da vida e apontam para profundos problemas interiores. Toda história mítica tem a função de harmonizar a vida dos indivíduos com a realidade efetiva. Em todas essas narrativas, vemos a busca dos personagens míticos na busca da iluminação e na tentativa constante de chegar próximo do sagrado ou de sua própria iluminação. Nesse momento de busca, temos consciência das imperfeições humanas e do sofrimento da vida. O contrário dessa situação seria, justamente, a transformação pela vida espiritual, lá estaria a perfeição. Dessa maneira, o mito revela aquilo que o homem tem de mais profundo, sua busca de entendimento e de verdade, de sentido e de significação da vida. Revela os mistérios do mundo e criam um fio condutor que o leva, e o acompanha, até a morte.

No momento no qual se situa esta pesquisa, as referências dos monarcas absolutos da Europa ocidental se encontram na Bíblia, nas hagiografias e nas literaturas gregas e latinas. Esses temas são reproduzidos pelas festas, pelas novelas de cavalaria e pelas fábulas que povoaram a mentalidade daquela época. Nelas, por meio de metáforas e parábolas, toda uma sorte de personagens representados por santos, reis, rainhas, juízes e heróis exercem seus papéis mitológicos e servem de exemplos, bons e ruins, para toda a coletividade. Pela importância e pelas explicações que trazem consigo, essas histórias se pretendem, antes de tudo, atemporais. Mas, pelas relações intimas que trazem com a realidade dos homens e dos grupos sociais, qualquer transformação histórica acarreta transformação nos mitos: 
[...] o mito é desgastado pelas transformações históricas e, quando isto acontece, ele perde sua eficácia simbólica, esgotando-se como fonte de explicação e guia de conduta, subsistindo apenas como tema literário e artístico desligando-se da esfera da coletividade. É nesse processo que o mito se torna folclore (MELLO E SOUZA, 2002, p. 308)

Mas, "[...] para as sociedades nas quais ele está presente de forma viva e atuante, o mito (como a ideologia) ajuda a estabelecer a identidade grupal, constitui a visão de mundo da comunidade" (FRANCO JR., 1996, p. 40). Por isso, ritos e gestos solenes precisam ser repetidos a exaustão como garantia de sobrevivência e uma forma de resistência às transformações do tempo.

A questão mais profunda para o momento que estudamos seria a própria valorização dos monarcas como os grandes defensores e propagadores da fé cristã entre os mouros e os americanos, fato esse que não se encontra na realeza inglesa ou francesa. As monarquias ibéricas são aquelas que, justamente, encontram-se envolvidas nas cruzadas de expulsão dos árabes muçulmanos de seus territórios e na conquista espiritual dos índios do Novo Mundo.

Frente a essa questão histórica, e ao surgimento de novos atores sociais, a monarquia centralizadora dos tempos modernos reelaboraria as cerimônias e as práticas herdadas da Idade Média. No momento, o que estava em jogo era a solidificação da autoridade do rei e de toda a sua burocracia de Estado. Por toda a Europa, vemos a ressurreição de ritos e maneiras buscadas na mais remota antiguidade como forma de criar um elo e uma identificação com figuras ilustres dos tempos clássicos. Em terras coloniais, justamente por conta da distância, seriam representados pelas festas religiosas, pelas celebrações das datas importantes para ao reino e pela devoção aos santos da casa real.

\section{Considerações Finais}

Por meio das festas e dos atos públicos, a vida cotidiana em Minas Gerais dava espaco para o maravilhoso e a colônia via-se, a todo instante, integrada em um organismo único no qual todos os indivíduos tinham seu lugar. Raymond Aron (1984, p. 329) coloca: "a cerimônia, atividade coletiva, arrasta os indivíduos para fora de si mesmos, faz com que participem da força do grupo". A igreja seria a comunidade moral de todos aqueles que aderem a essa crença. O poder temporal, relacionado ao poder espiritual, traria uma sensação única de coletividade. Vemos assim que, antes de tudo, o mito, na sua versão religiosa ou política, apresentava uma função pedagógica. Temos, desse modo, uma sociedade codificada que prepara uma encenação política que anda de mãos dadas com a teologia; uma jurisprudência baseada em cânones retóricos; indivíduos que se comportam e se entendem na encenação de um grande teatro.

Para atingir esse efeito, a imaginação do artista cobriria as lacunas e traria novas interpretações. Para isso, utilizava-se dos evangelhos apócrifos, tratados de etiqueta e de usos e costumes da época. A partir daí, inaugura-se, em solo mineiro, uma tradição que se utilizou de artifícios literários pagãos para propósitos cristãos, abrindo caminho para a composição das imagens e possibilitando o uso de símbolos e alegorias na literatura e na arte religiosa. A partir dessa tradição, temos a fundação de toda a literatura árcade mineira e da visualidade cristã daqueles indivíduos.

\section{Referências}

ALVES, C. M. Artistas e irmãos: o fazer artístico no ciclo do ouro mineiro. 1997. Dissertação (Mestrado em História Social) - Faculdade de Filosofia, Letras e Ciências Humanas, Universidade de São Paulo, São Paulo, 1997. 
Um estudo iconográfico. In: COELHO, Beatriz (org.). Devoção e arte: imaginária religiosa em Minas Gerais. São Paulo: Edusp, 2005. ARAÚJO, A. C. Despedidas triunfais - celebração da morte e cultos de memória no século XVIII. In: KANTOR, Íris; JANCSÓ, István (Org.). Festa: cultura e sociabilidade na América portuguesa. São Paulo: Edusp/Fapesp/Imprensa Oficial/Hucitec, 2001.

ARAÚJO, E. (Org.). O universo mágico do barroco brasileiro. São Paulo: FIESP, 1998.

ARENAS, J. F; BASSEGODA I HUGAS, B. (Ed.). Barroco en Europa. Barcelona: Gustavo Gili, 1983.

ARON, R. Etapas do pensamento sociológico. São Paulo: Martins Fontes, 1984.

ÁVILLA, A.; MACHADO, R. e GONTIJO, J. M. M. Barroco Mineiro: Glossário de Arquitetura e Ornamentação. Belo Horizonte: Fundação Joao Pinheiro, 1994.

ATIENZA, J. Os santos pagãos: deuses ontem, santos hoje. São Paulo: İcone, 1995.

BAUMGARTEN, J. Perspectiva polifocal e iconografia pós-tridentina segundo o exemplo de Conceição da Praia em Salvador da Bahia. La Revista Chilena de Antropología Visual, La Universidad Academia de Humanismo Cristiano, Santiago, n. 4, p. 300-316. jul. 2004. Disponível em: <http://www.academia.cl/rev_antrop_visual/ revista4/Jens_Baumgarten.htm>. Acesso em: 03 ago. 2011.

CARRAZONI, M. E. Guia dos bens tombados. Rio de Janeiro: Exped, 1980.

CARVALHO, M. do S. F. de. Poesia de agudeza em Portugal. São Paulo: Humanitas Editorial/ Edusp/Fapesp, 2007.

CHEVALIER, J.; GHEERBRANT, A. Dicionário de símbolos. Rio de Janeiro: José Olympio, 2009.

COELHO, B. (Org.). Devoção e arte: imaginária religiosa em Minas Gerais. São Paulo: Edusp, 2005.

CUNHA, M. J. A. da. Iconografia Cristã. Ouro Preto: UFOP/IAC, 1993.
CURTO, D. R. O discurso político em Portugal: 1600-1650. Lisboa: Centro de Estudos de História e Cultura Portuguesa,1998. (Colecção Temas de Cultura Portuguesa, 12).

DEL PRIORE, M. Festas e utopias no Brasil colonial. São Paulo: Brasiliense, 1994.

DE VARAZZE, J. Legenda áurea: vidas de santos. São Paulo: Companhia das Letras, 2003.

DIAS, M. H. G. Entre a cristã e a estética cortesã: a pintura de corte em Minas colonial. 2000. Dissertação (Mestrado em Histórias Social) - Faculdade de Filosofia, Letras e Ciências Humanas, Universidade de São Paulo, São Paulo, 2000.

FARACO, C. E.; MOURA, F. M. Gramática. São Paulo: Ática, 1996.

FRANCO JR., H. A Eva barbada: ensaios de mitologia medieval. São Paulo: EDUSP, 1996.

FURTADO, J. F. Pérolas Negras: mulheres livres de cor no Distrito Diamantino. In: . Diálogos

Oceânicos: Minas Gerais e as novas abordagens para uma história do Império Ultramarino Português. Belo Horizonte: Ed. UFMG, 2001.

FRONER, Y. A. Os símbolos da morte e a morte simbólica: um estudo do imaginário na arte colonial mineira. 1994. Dissertação (Mestrado em História Social) - Faculdade de Filosofia, Letras e Ciências Humanas, Universidade de São Paulo, São Paulo, 1994.

GALDIERI, M. C. C. C. A pintura do barroco mineiro do ciclo do ouro: mitos e história. Tese (Doutorado em Antropologia) - Faculdade de Filosofia, Letras e Ciências Humanas, Universidade de São Paulo, São Paulo, 1990.

HANSEN, J. A. Alegoria: construção e interpretação da metáfora. São Paulo: Atual, 1986.

Barroco-estilo. Ouro Preto: IFAC/UFOP, 1999. (Texto cedido pelo Instituto de Arte e Cultura de Ouro Preto).

Barroco, neobarroco e outras ruínas.

Teresa: Revista de Literatura Brasileira, Departamento de Letras Clássicas e Vernáculas/ FFLCH-USP, São Paulo, n. 2. s.d. 
Colonial e barroco. América: descoberta ou invenção. Rio de Janeiro: Imago, 1992. ( $4^{\circ}$ Coloquio UERJ)

Notas 7 - Pós-Graduação Lato Sensu. Ouro Preto: IFAC-UFOP, 1999 (Apostila n 07).

Notas 8 - Pós-Graduação Lato Sensu. Ouro Preto: IFAC-UFOP, 1999. (Apostila $n^{\circ} 08$ ).

HESPANHA, Antônio Manuel. As estruturas políticas em Portugal na época moderna. In: TENGARRINHA, J. (Org.). História de Portugal Bauru: Edusc/São Paulo: Unesp/ Portugal: Instituto Camões, 2001.

A representação da sociedade e do poder. In: MOTTOSO, José (Dir.). História de Portugal. Lisboa: Editorial Estampa, 1993.

KITSON, M. O Barroco. Rio de Janeiro: José Olympio, 1966.

LIMA JR., A. História de Nossa Senhora em Minas Gerais. Belo Horizonte: Autêntica e PUC Minas, 2008.

LODI, E. Os santos do calendário romano. São Paulo: Paulus, 2001.

MAIA, P. M. Os cinco sentidos, os trabalhos dos meses e as quatro partes do mundo em painéis de azulejos no convento de São Francisco, em Salvador, Bahia. Salvador: s.e., 1990.

MARINO, J. Iconografia de Nossa Senhora e dos Santos. São Paulo: Banco Safra - Projeto Cultural, 1996.

MELLO E SOUZA, L. Festas barrocas e vida cotidiana em Minas Gerais. In: KANTOR, Íris; JANCSÓ, István (Orgs). Festa: cultura e sociabilidade na América portuguesa. v. 1. São Paulo: Edusp/Fapesp/Imprensa Oficial/Hucitec, 2001.
OLIVEIRA, M. A. R.; SANTOS FILHO, O. R. dos; SANTOS, A. F. B dos. O Aleijadinho e sua oficina: catálogo de esculturas devocionais. São Paulo: Capivara, 2002.

PAIVA, J. P. Etiqueta e cerimônias públicas na esfera da Igreja (séculos XVII-XVIII). In. KANTOR, Í; JANCSÓ, I. (Orgs). Festa: cultura e sociabilidade na América portuguesa. v. 1. São Paulo: Edusp/ Fapesp/Imprensa Oficial/Hucitec, 2001.

PEREIRA, J. F. P. Dicionário de arte barroca em Portugal. Lisboa: Editorial Presença, 1989.

PRAZ, M. P. Imágenes del Barroco: Estudios de Emblemática. Madrid: Ediciones Siruela, 1989.

Literatura e artes visuais. São Paulo: Cultrix, 1982.

RIPA, C. Nova Iconologia. Milano: Editori Associati, 1992.

SOUZA, M. de M. Reis Negros no Brasil Escravista: História da Festa de Coroação do Rei Congo. Belo Horizonte: Editora da UFMG, 2002. SOUZA, W. A. de (Coord.). Guia dos bens tombados: Minas Gerais. Rio de Janeiro: Expressão e Cultura, 1984.

TIRAPELI, P. (Org.). Arte sacra colonial: barroco memória viva. São Paulo: Editora da UNESP, Imprensa Oficial do Estado, 2001.

Arte sacra: gênese da fé no novo mundo. São Paulo: Imprensa Oficial, 2007. (Coleção arte no acervo dos palácios de São Paulo)

ZANINI, W. História geral da arte no Brasil. São Paulo: Instituto Walter Moreira Salles/ Fundação Djalma Guimarães, 1983.w 